\title{
Os novos contornos do bacharelismo liberal: uma análise da trajetória de Candido Motta (1870-1942)
}

Marcos César Alvarez' Fernando Salla ${ }^{2}$

\section{Resumo}

A proposta do artigo consiste em analisar alguns aspectos da atuação intelectual e política de membros das elites jurídicas brasileiras na Primeira República (1889-1930), nos quadros do assim chamado bacharelismo liberal. A Antropologia Criminal ou Nova Escola Penal pretendeu inovar no campo tanto do Direito quanto da Medicina no período, o que permitiu a projeção intelectual e política de alguns médicos e juristas defensores dessa "escola". Apresentamos aqui a trajetória de Candido Motta que, além de contar com relações de pertencimento às elites, conseguiu se projetar como intelectual, professor da Faculdade de Direito em São Paulo e, sobretudo, como político, a partir da condição de um dos principais defensores e disseminadores da Nova Escola Penal em São Paulo.

Palavras-chave: Juristas. Direito Penal. Criminologia. Cultura Jurídica.

Se vogliamo che tutto rimanga come $\dot{e}$, bisogna che tutto cambi

Giuseppe Tomasi di Lampedusa

\footnotetext{
1 Professor Livre Docente do Departamento de Sociologia da Universidade de São Paulo; pesquisador do Núcleo de Estudos da Violência da USP; bolsista de produtividade em pesquisa pelo Conselho Nacional de Desenvolvimento Científico e Tecnológico (CNPq).

2 Sociólogo, pesquisador associado do Núcleo de Estudos da Violência da Universidade de São Paulo (NEV-USP).
}

\section{(c)) EY}

Direito autoral e licença de uso: Este artigo está licenciado sob uma Licença Creative Commons. Com essa licença você pode compartilhar, adaptar, para qualquer fim, desde que atribua a autoria da obra, forneça um link para a licença, e indicar se foram feitas alterações. 


\section{Introdução: os juristas como intelectuais no Brasil $^{3}$}

Os profissionais da lei podem ser chamados de intelectuais? ${ }^{4}$ Se, na atualidade, os diversos operadores do Direito atuam, tanto no âmbito da política e do Estado quanto no campo da sociedade e da cultura, tendo por base um saber especializado - desempenhando, desse modo, junto com outros profissionais das ciências, o papel de "intelectuais específicos", tal como uma vez definido por Michel Foucault (1979) -, no passado da América Latina, os juristas já ambicionaram um espaço muito mais amplo de atuação. Efetivamente, advogados e juristas tiveram participação decisiva nos processos de independência e de formação dos Estados nacionais latino-americanos, mas igualmente sua influência no campo da cultura não foi menor, uma vez que os graduados em Direito, em meados do século XIX, eram os letrados por excelência, vistos como portadores de um saber superior, que os habilitava tanto aos assuntos do Estado, quanto à reflexão sobre a sociedade e à atuação cultural (PERDOMO, 2008).

Em relação à formação dos bacharéis e ao desenvolvimento das carreiras jurídicas, a situação brasileira apresenta algumas particularidades, tendo em vista os demais países latino-americanos. Ao passo que, na América espanhola, os estudos jurídicos foram estabelecidos já no século XVI, no Brasil colonial o ensino jurídico permaneceu subordinado à metrópole, tanto no que diz respeito à legislação vigente, quanto à formação das burocracias locais e à produção e difusão das ideias jurídicas. A formação universitária dos estudantes brasileiros ocorria, sobretudo, na Universidade de Coimbra, sendo essa dependência da formação das elites locais um importante instrumento de subordinação política frente à metrópole (VENÂNCIO FILHO, 1982). Desse modo, a partir da Independência, a criação dos cursos jurídicos no País - em Olinda-Recife e em São Paulo - buscou criar condições para a formação de uma nova elite política

30 presente trabalho foi elaborado a partir de fontes em parte levantadas no âmbito da pesquisa Construção das Políticas de Segurança e o Sentido da Punição, São Paulo (1822-2000), realizada pelo Núcleo de Estudos da Violência da Universidade de São Paulo (NEV-USP), com recursos da Fundação de Amparo à Pesquisa no Estado de São Paulo (FAPESP), dentro do Programa Centros de Pesquisa, Inovação e Difusão (CEPID). Agradecemos a participação nesse projeto dos pesquisadores Eder Marques Loiola e Kelly Ludkiewicz Alves que foram responsáveis pela coleta de algumas informações sobre Cândido Motta.

4 Retrabalhamos, nesta introdução, a discussão apresentada em Alvarez (2003, 2014). 
local, embora paradoxalmente Coimbra continuasse servindo de modelo institucional para as faculdades brasileiras e a cultura jurídica portuguesa tenha permanecido como influência dominante no País, principalmente durante a primeira metade do século XIX (MACHADO NETO, 1969; SIMÓES NETO, 1983). Outra particularidade brasileira consistiu no fato de que a dominância dos intelectuais do Direito prolongou-se ainda com a República, sendo que o ensino jurídico passou por importante renovação nas últimas décadas do século XIX, sobretudo com a reforma de Benjamim Constant, em 1891, que pôs fim ao monopólio de Recife e São Paulo e viabilizou a criação de faculdades livres em diversos estados.

Antonio Cândido (1956) já havia apontado para o papel dominante dos juristas no século XIX como intérpretes por excelência da sociedade brasileira. Sem dúvida, a renovação do ensino jurídico e as mudanças na política e no Estado, com a República, levaram, por um lado, a que bacharéis e juristas diversificassem seus horizontes intelectuais e seus espaços de atuação nas décadas seguintes. No âmbito do Direito Penal, por exemplo, a recepção das discussões que ocorriam na Europa em torno dos trabalhos de Cesare Lombroso e de seus seguidores, incorporadas pelos juristas brasileiros como sendo a "Nova Escola Penal" (CASTRO, 1890) ou "a Escola Positiva" - entre outras denominações, em oposição à assim chamada "Escola Clássica" de Direito Penal - abriram espaço para novos debates doutrinários e igualmente para iniciativas legais e institucionais (ALVAREZ, 2003). Por outro lado, com a República, tanto as faculdades de Direito foram perdendo gradativamente a hegemonia em termos de formação política e cultural das elites locais, em proveito de maior especialização do ensino jurídico e de uma formação mais profissional dos bacharéis, quanto passaram a sofrer a concorrência de médicos, de educadores, de engenheiros e de outros profissionais na busca de um novo paradigma de interpretação e de modernização do País. A competição crescente dos "homens de ciência" no período reconfigurou a atuação tradicional do bacharel liberal, legado do século anterior (HERSCHMAN, 1994; SCHWARCZ, 1993; SÁ, 2006), mas essa própria disputa acabou disseminando, nas décadas seguintes, certo desinteresse pelo estudo desses setores das elites ao longo do século XX. O "bacharelismo" tornou-se sinônimo de saber retórico e vazio 
e as disciplinas jurídicas foram assimiladas a conhecimentos puramente conservadores (SCHWARTZMAN, 1987).

$\mathrm{Na}$ contracorrente dessa desvalorização dos estudos sobre os bacharéis, Sérgio Adorno realizou pesquisa sobre a formação profissional na Faculdade de Direito de Sáo Paulo, no período de 1827 a 1883, indicando como a formação política e cultural do bacharel ocorria para além do ensino formal na Faculdade de Direito. Como já havia afirmado anteriormente Venâncio Filho (1982), o autodidatismo era uma das principais características dos juristas locais, já que novas ideias artísticas, sociais e políticas eram discutidas pelos estudantes de Direito, principalmente a partir da segunda metade do século XIX, mas essa discussão ocorria fora das salas de aula e longe dos mestres. Ou seja, as faculdades de Direito no País se configuraram mais como espaços voltados para a formação cultural e política das elites do que como espaços de reflexão original acerca do Direito e da ordem jurídica. Para Adorno, no que dizia respeito especificamente à faculdade de Direito de São Paulo durante o Império, foi justamente a desilusão com o conhecimento jurídico ensinado em sala de aula que estimulou a criação de institutos e de associaçóes acadêmicas, espaços efetivos de formação cultural e política dos futuros bacharéis. Tal formação foi “[...] tecida nos interstícios dos institutos acadêmicos e do jornalismo literário e político." (ADORNO, 1988, p. 157).

Pelas razões apontadas, o "bacharelismo liberal" local não permaneceu inalterado com a República. Seguindo a trilha aprofundada por Adorno, podemos questionar de que modo, já no período republicano, ocorreram mudanças na formação dos profissionais do Direito no Brasil, no perfil desse setor das elites e nas formas de intervenção na sociedade gestadas a partir do campo jurídico.

Nos demais países da América Latina, já durante o transcorrer do século XIX, a incorporação do positivismo europeu pelas elites latino-americanas possibilitou toda uma recolocação dos temas jurídicos em chave diversa daquela da tradição liberal (PERDOMO, 2008), o mesmo tendo ocorrido no Brasil, na passagem do século XIX para o XX. Por exemplo, as ideias que, grosso modo, podem ser definidas como pertencentes ao campo da Criminologia circularam entre juristas brasileiros - sempre ladeados, 
nesse campo, pelos médicos - e viabilizaram o estabelecimento de redes de cooperação intelectual bem como de novos espaços de atuação profissional (CORREA, 1982; ALVAREZ, 2003, 2005; FERLA, 2005; DIAS, 2015).

O estudo da trajetória de formaçáo e de atuação de membros das elites jurídicas no período poderia avançar e complementar o estudo das ideias e de seus efeitos. Neste artigo, tendo em vista o horizonte de problemas anteriormente delimitado, pretendemos esboçar uma análise da trajetória intelectual e política do jurista paulista Candido Motta (1870-1942) como uma forma de identificar mudanças na atuação dos bacharéis em São Paulo já nas primeiras décadas do século XX.

\section{Candido Motta: professor, político e polígrafo}

Candido Motta foi advogado, formado na Faculdade de Direito de São Paulo, promotor público, delegado de polícia, professor na cadeira de Direito Penal no Largo São Francisco, autor de estudos na área da Antropologia Criminal e de ensaios históricos, deputado e senador estadual pelo Partido Republicano Paulista (PRP), autor do projeto que criou o Instituto Disciplinar para menores, secretário da Agricultura, Comércio e Obras Públicas, presidente do Conselho Penitenciário, tendo ainda exercido atividade jornalística ${ }^{5}$. Sua trajetória indica novas estratégias políticas e intelectuais possíveis, mobilizadas pelos membros das elites jurídicas para consolidar suas posiçóes no aparato de Estado republicano em expansão e no território acadêmico que começava a se diversificar e especializar, a partir das primeiras décadas do século XX.

Sob muitos aspectos, Candido Motta passa a ser um representante típico das elites jurídicas, da Primeira República, ao se tornar bacharel pela Faculdade de Direito, locus essencial para a construção de sua carreira

5 A atividade jornalística, segundo Miceli (1979), é, no período da República Velha (1889-1930), uma das principais atividades do campo da cultura, uma vez que o jornal se constituía em espaço privilegiado de divulgação e consagração intelectual. Embora não se tenha notícia de que integrasse regularmente o quadro de jornalistas, nos anos de 1920. Motta assinou uma série de matérias no jornal Correio Paulistano que representava uma espécie de memória de acontecimentos passados, descrevendo como havia sido seu concurso de ingresso como professor na Faculdade de Direito (Por que e como me tornei professor da Faculdade de Direito de São Paulo - janeiro de 1927) e os casos policiais na época em que atuou como delegado de polícia (coluna Águas Passadas - janeiro a julho de 1928 e julho de 1929). 
política e profissional. Ao longo de sua trajetória, ele mobilizou o capital social e político da oligarquia a que pertencia para a ocupação de sucessivos cargos na administração pública e na vida política. Seu ingresso como professor na Faculdade de Direito e seus passos iniciais como político serão possíveis a partir de seu papel como um dos "pioneiros" da Antropologia Criminal e da "Nova Escola Penal" no País. Efetivamente, Candido Motta estabeleceu redes de contatos nacionais e internacionais - por exemplo, recepcionando Enrico Ferri em São Paulo e cooperando com Paulo Egídio e Nina Rodrigues, entre outros, no País - e escreveu obras inspiradas nas "conquistas" da Nova Escola, o que igualmente impulsionou sua carreira política, já que seus atributos intelectuais foram inúmeras vezes destacado por seus contemporâneos.

O jurista Noé Azevedo, por exemplo, em homenagem póstuma, realizada na Congregação da Faculdade de Direito, em 1942, ao caracterizar a "obra científica" de Candido Motta, define o jurista como "[...] um dos pioneiros do movimento [da Escola Positiva] no Brasil, como continuou sendo durante mais de 40 anos o combatente mais convicto." (AZEVEDO, 1942, p. 318). Evidentemente, Azevedo seguia as convençóes das homenagens do gênero ao exagerar o papel de Candido Motta na cruzada pela "Nova Escola", uma vez que, desde o final do século XIX até a quarta década do século XX, diversos outros juristas e médicos brasileiros haviam abraçado, com diferentes matizes, as ideias biodeterministas no âmbito da explicação e da intervenção no fenômeno criminal, no sentido de sua patologização (ALVAREZ, 2003, 2005; FERLA, 2005; AUGUSTO; ORTEGA, 2011; DIAS, 2015).

Azevedo, substituto de Motta na cátedra de Direito Penal da Faculdade de Direito de Sáo Paulo, e ele próprio divulgador das mesmas ideias da Escola Positiva, sobretudo no que dizia respeito à criaçáo de um novo tratamento jurídico para os menores delinquentes (AZEVEDO, 1920), colocava-se assim como um herdeiro do "estilo revolucionário" de Motta na defesa das ideias de Lombroso, Ferri, Garofalo bem como nos sistemáticos ataques à instituição do júri. Azevedo não deixará de destacar o papel central de Motta na criação do Instituto Disciplinar para Menores (1902), que teve origem no projeto de 1900 para a instalação do "Instituto Educativo Paulista”. 
A homenagem de Azevedo, que será praticamente repetida no ano do centenário do nascimento de Motta (AZEVEDO, 1970), é sintomática, sobretudo por reafirmar o perfil da trajetória de Motta que ficará para a posteridade: jurista inovador, adepto das ideias da Nova Escola, criador do Instituto Disciplinar etc.

A se tomar como correta a afirmação de Adorno (1988) de que na Faculdade de Direito de Sáo Paulo, mais que ensinar doutrina ou formar juristas, o importante, ali, no século XIX, foi a formação de quadros para ocuparem os principais cargos na estrutura do Estado, Candido Motta, formado no final do século, não deixou de reproduzir esse padrão, se observamos sua trajetória política e no Estado. No entanto, ele mobilizou um novo repertório de ideias "científicas" no terreno do Direito Penal, que levou igualmente para as salas da Faculdade do Largo São Francisco, e a reputação de "apóstolo" da Nova Escola não deixou de acompanhá-lo, ao longo da carreira política e administrativa. É por esse caminho que sua trajetória apresenta novidades, por ter construído um percurso diferenciado na ocupação de cargos políticos e ter sido decididamente figura relevante na conformaçáo de aspectos do aparato de controle social nas primeiras décadas do século XX em São Paulo.

\section{Rumo à carreira de bacharel e professor na Faculdade de Direito do São Francisco ${ }^{6}$}

Candido Nazianzeno Nogueira da Motta nasceu no dia 9 de maio de 1870, em Porto Feliz, no interior da então Província de São Paulo. Seu pai, Fernando Maria Nogueira da Motta, foi professor secundário e diretor de colégio na cidade de Amparo. Pelo lado da máe, Mariana Francisca da Motta, seu avô teria sido fazendeiro em Capivari. Além disso, Candido

6 Para a reconstituição da biografia de Motta, aqui realizada, recorremos a fontes diversas: artigos de homenagem, obras jurídicas do próprio autor, relatórios, pareceres e demais publicações oficiais que registram a atuação de Motta nas diversas posições institucionais que ocupou na área da justiça criminal e da segurança; debates parlamentares, que apresentam as discussões no âmbito do Legislativo estadual, nas quais Motta se envolveu em sua atividade política; o livro de memórias produzido por seu filho, Cândido Motta Filho (1972); registros oficiais acerca da atividade de Motta como lente da Faculdade de Direito de São Paulo, como seu prontuário disponivel no Arquivo da FDUSP. Por fim, foi realizado levantamento na imprensa paulista, de 1890 até a morte da Candido Motta, em 1942. 
Motta teria, como parentes do lado paterno, Candido José da Motta, um tio de seu pai que havia ocupado a secretaria do Padre Diogo Antônio Feijó durante a revolta de parte dos liberais, em 1842, e Cesário Motta Júnior, "político de prestígio" e, juntamente com o tio de Motta pai, participante da Convenção de Itu. Do lado materno, Motta seria aparentado de Júlio César Ribeiro Vaughan, professor e escritor naturalista, casado com uma de suas tias (MICELI, 1979). ${ }^{7}$

Candido Motta iniciou seus estudos na Faculdade de Direito de São Paulo, aos 18 anos, onde se formou bacharel em 1891. Logo no início de 1892 foi nomeado promotor público para a cidade de Amparo. As interaçôes políticas do jovem bacharel ficam evidentes com a manifestação do jornal Correio Paulistano (órgão do Partido Republicano Paulista), que saúda a nomeação do "nosso distinto amigo e correligionário". E, em seguida: "O digno moço foi um dos diretores do movimento revolucionário de Capivari, contra o governo do sr. Américo Brasiliense, e prestou com isso os mais relevantes serviços ao Estado." (CORREIO PAULISTANO, 1892, p. 1). ${ }^{8}$

Sua permanência no interior foi breve, pois, em 1893, já estava atuando como promotor público na capital de São Paulo, cargo no qual permanece até 1896. Na condiçáo de promotor público, participava ativamente das sessóes do tribunal do júri, fazia visitas às prisões (CORREIO PAULISTANO, 1894 , p. 1, 1895, p. 1) $)^{9}$, participava como "curador fiscal" de empresas que estavam em processo de falência etc. É bem provável que, já naquele momento, tenha entrado em contato com as ideias da Nova Escola Penal. Assim, na condição de promotor público, elabora um Relatório relativo ao ano de 1894 (MOTTA, 1895) que estabelece um estilo diferenciado de apresentação e de argumentação em relação aos dados sobre a criminalidade.

Em linhas gerais, o relatório intitulado A Justiça Criminal na Capital do Estado de São Paulo presta-se à descrição dos dados da justiça criminal

\footnotetext{
7 Ver também: REVISTA DA FACULDADE DE DIREITO (1942). Consultar, sobre o assunto, a apresentação da edição (p. 7-II).

8 Todos os jornais mencionados neste artigo foram consultados por meio da Hemeroteca Digital da BibliotecaNacional. Disponivel em: <http://bndigital.bn.gov.br/hemeroteca-digital/>.

9 As visitas eram destinadas a ouvir "atentamente as reclamações dos presos".
} 
na capital no ano de 1894 . Motta, no entanto, ao longo do texto, propóe interpretaçóes e medidas preventivas com base no material estatístico. Logo na página de rosto do relatório, o caráter propositivo do autor é insinuado por meio da citação de uma frase de Stuart Mill, segundo a qual "Só é possível mudar aquilo que conhecemos". O relatório é divido em seções relativas, nessa ordem, aos números de processados, aos números de julgados e sentenciados, aos fatores que levariam aos delitos, e às discussóes sobre a prevenção da criminalidade.

Antes de apresentar e comentar os dados, contudo, Motta faz críticas profundas à organização da Justiça no novo regime republicano. Para o relator, o republicanismo não haveria efetuado, até o momento, as reformas necessárias à área, o que tornava o seu funcionamento débil, inadequado aos padróes do novo contexto sócio-político:

O 15 de novembro [...] não produziu ainda [...] todas as suas consequências lógicas e necessárias, principalmente no que diz respeito à organização judiciária, [às] leis criminais, de processo e pública segurança. (MOTTA, 1895, p. 6).

Ou seja, as reformas jurídico-penais, vistas como necessárias e mesmo lógicas no contexto do novo regime, não haviam sido ainda implementadas. Essa afirmação parece referir-se abertamente à frustração dos juristas da Nova Escola Penal, da qual Motta fazia parte, com a homologação do Código Penal de 1890, de inspiraçáo liberal clássica (ALVAREZ, 2003). Entre as críticas que Motta faz à situação da justiça no novo contexto republicano, uma se destaca, a saber, a crítica à dependência do Ministério Público em relaçáo às demandas extrajudiciais. $O$ órgáo náo estaria cumprindo seu papel de órgão independente, cujo objetivo seria a defesa da sociedade em relação à criminalidade. Não estaria cumprindo indiretamente, dado o número exíguo de seus funcionários, e diretamente, já que era dirigido por interesses políticos:

Sujeitar o Ministério Público às influências políticas e às paixões partidárias é tirar-lhe a liberdade de ação e, portanto, anulá-lo, desprestigiá-lo, é inverter a sua verdadeira missão como órgão da justiça. (MOTTA, 1895, p. 7).

Ao entrar na discussão dos dados da justiça criminal da capital, Motta começa por apresentar os números referentes a processos movidos por 
policiais, de acordo com a modalidade de crime ou infração. Nesse ponto, a argumentação de Motta se destaca pelas severas críticas à vagabundagem, segundo ele infração intensamente reprimida na capital. Os vagabundos e ociosos, degenerados por natureza, guardariam os germes antropológicos para a formação de outros tipos de criminosos. Assim, a tarefa do Estado de defesa social estaria sendo plenamente realizada:

E é justamente nesta capital que deve haver maior rigor na repressão da ociosidade [...] porque os nossos vagabundos são verdadeiros degenerados, pois não temos causas econômicas e morais que os justifiquem. (MOTTA, 1895, p. 10-11).

É necessário dizer que a análise de Motta é baseada novamente em princípios básicos da Antropologia Criminal, o que mostra como o relatório e, por extensão, a promotoria da capital admitiam critérios teóricos de interpretação da criminalidade que não os estabelecidos no Código de 1890. Fica clara, nesse texto, a influência das ideias criminológicas que o informavam quando Motta, em relação aos vagabundos, atribuía às causas biológicas individuais desses indivíduos, e não às condiçóes sociais, a responsabilidade pela infração, concepção clássica dos seguidores de Lombroso.

Motta, ao tratar dos vários crimes praticados em São Paulo, constata o número considerável de estrangeiros, trabalhadores, mulatos e negros nas estatísticas referentes aos processados, na maioria de modalidades de crime. $\mathrm{Na}$ tentativa de explicar os fatores dos delitos, Motta aponta três categorias: os fatores ligados às condiçóes físicas naturais de São Paulo, os fatores sociais e os fatores antropológicos.

Quanto aos primeiros fatores, Motta divide os números relativos aos crimes contra a pessoa e contra a propriedade e às contravençóes de acordo com sua ocorrência nos meses do ano e constata:

[...] verifica-se que não houve diferença sensível entre os crimes praticados contra a pessoa e a propriedade nos meses em que o calor atingiu o seu máximo e igualmente o frio, de modo a nada se poder concluir sobre a influência termométrica nesta ou naquela espécie de crime. (MOTTA, 1895, p. 29).

Dessa forma, para Motta, os fatores físicos do meio não teriam tanta influência na etiologia do crime na capital de São Paulo durante o ano de 
1894. O peso das causas sociais também não seria determinante, já que as condiçôes de São Paulo não favoreceriam o crime: possibilidade segura de subsistência, clima ameno propiciando diversas atividades produtivas, indústria em crescimento, Estado liberal etc.

No que se refere aos fatores antropológicos do crime, isto é, aqueles fatores ligados às esferas do biológico e do biossocial individual, teriam esses motivos a maior parcela de responsabilidade na manifestação de crimes e contravençóes na capital. Para analisar esses fatores, Motta os desagrega em itens como a cor, a idade, o estado civil etc. e estabelece algumas relaçóes entre esses critérios e os números de certos crimes. Os latinos, por exemplo, "de sangue quente", seriam, por esse motivo, os principais agentes de crimes contra a pessoa. Chama a atenção a caracterização do negro e dos desdobramentos criminais. Analisando alguns casos de maior gravidade (estupros, homicídios etc.), Motta assim caracteriza um negro, acusado pelo assassinato de uma mulher:

"B. D., preto de 20 anos, brasileiro, nascido neste Estado, trabalhador da roça. Parece mais um antropoide que um homem. É neto de africanos. O seu prognatismo é muito visível e completo, bem como sua microcefalia. É imberbe, mas tem bastante pelos encarapinhados na cabeça [...] sendo de notar que o crime [por ele praticado] foi premeditado e realizado de um modo horroroso. (MOTTA, 1895, p. 44).

Segundo Motta, os negros seriam tipos criminais que, no caso de crimes contra as pessoas, embora os cometessem com menos frequência em relação aos brancos, os revestiam com requintes de crueldade. Essa tentativa de caracterizaçáo das circunstâncias do crime a partir dos dados biológicos, bem como os esforços de identificação das causas climatológicas do crime, revelam um aspecto já comentado das teses de Lombroso e seus seguidores, largamente empregado no relatório de Motta, qual seja, a incorporação de dados diversos nas explicaçôes sobre as origens da criminalidade. Embora alguns de seus excessos naturalistas fossem comentados mesmo por contemporâneos, é interessante notar como a Antropologia Criminal logrou obter certo grau de credibilidade para os especialistas da justiça e da segurança e, dessa forma, instrumentalizou-se em meio de controle, ao menos simbólico, de certos segmentos sociais, como bem o mostra o relatório discutido. 
O interesse em relação aos novos conhecimentos criminológicos da época levará Cândido Motta a elaborar um trabalho de cunho mais teórico, que apresentará na Faculdade de Direito de Sáo Paulo para disputar o lugar de substituto na cadeira de Direito Penal. O livro, publicado em 1897 e visto por muitos contemporâneos como um momento decisivo do "triunfo" da Nova Escola Penal no Brasil, tinha por título "Classificação dos Criminosos” e foi reeditado em 1925. No prefácio da reedição, Motta agradecia a boa recepção que a obra havia obtido tanto entre autores brasileiros - como Nina Rodrigues, Clóvis Beviláqua e Afrânio Peixoto, entre outros - como no exterior, onde se destacaria a citação de Ferri e, sobretudo, o suposto elogio do próprio Lombroso (MOTTA, 1925, p. 6).

Os jornais da época ao menos confirmam parte dessas redes de cooperação entre intelectuais locais e europeus em torno das ideias da Nova Escola. Por exemplo, ainda no ano de 1894, o jornal Correio Paulistano mencionava as relaçóes que Candido Motta já mantinha com um dos mais representativos pensadores da criminologia positivista:

O dr. Candido Motta, digno promotor público da capital recebeu há dias um folheto do ilustre criminalista italiano Enrico Ferri no qual vem o discurso que este pronunciou na câmara italiana sobre as leis de exceção sobre o socialismo e anarquismo. Nesse discurso o sr. Ferri distingue o socialismo do anarquismo. O folheto foi enviado ao dr. Candido Motta com uma honrosa dedicatória. (CORREIO PAULISTANO, 1894, p. 2).

Outro aspecto que mostra as articulaçóes intelectuais de Candido Motta no terreno da Criminologia e da Medicina Legal é a sua condição de "correspondente nesta capital" da Revista Médico-legal da Bahia que, em 1895, o médico Nina Rodrigues acabava de criar (CORREIO PAULISTANO, 1995, p. 1). Na mesma direção, Candido Motta participa da instalação, em São Paulo, da Sociedade de Antropologia, Ciências Penais e Medicina Legal. A solenidade foi presidida por Amâncio de Carvalho e secretariada por Candido Motta e Alcântara Machado. Estiveram também presentes Brasílio Machado, Pedro Lessa e João Monteiro (O COMMERCIO DE SÃO PAULO, 1895, p. 1).

Parece certo que a entrada mais contundente de Candido Motta nas questôes criminais vem exatamente com a sua condição de delegado de polícia, uma vez que, como promotor, ele estava envolvido também em casos 
de natureza muito diversa e sem necessariamente ligação com aquelas questôes. Em 1896, quando se torna delegado, sua participação nas operações diretas, na instauração dos inquéritos, oitivas, encaminhamentos de feridos, testemunhas etc. se torna muito intensa. Mas, ao lado das atividades de rotina de um delegado, Candido Motta encontrava espaço para algumas incursóes que o qualificavam como uma referência no terreno da criminologia:

O dr. Candido Motta, $2^{\circ}$ delegado e o dr. Archer de Castilho, médico-legista, do meio-dia às três horas da tarde, estiveram ontem na cadeia pública onde fizeram quatro longos e minuciosos exames de antropometria em criminosos assassinos e ladrões. Esta medida, de muita utilidade e prática, é mais um bom serviço e o dr. Xavier de Toledo [então chefe de polícia] que, estabelecendo, à maneira do que se pratica na Europa, teve em vista evitar, pelas múltiplas dimensões do corpo do indivíduo examinado, que um criminoso se apresente às vezes com um nome suposto. (O COMMERCIO DE SÃO PAULO, 1986, p. 2).

Embora já tivesse expressado algumas reflexões sobre a prostituição e o cafetismo no relatório ao procurador-geral mencionado acima, Motta, como delegado, teve atuação em relação a essas questóes. Escreve Prostituição, Polícia de Costumes, Lenocínio, em que expressa preocupação em reprimir os atentados contra a moral e os bons costumes, sobretudo a prostituição. No texto escrito por Motta, em 1897, são discutidos pelo autor diversos assuntos relativos às alternativas para a minimização dos efeitos da prostituição, sua relação com o crime de cafetismo, o papel do Estado no combate às demonstraçóes públicas de prostituição, entre outros temas.

Candido Motta teria sido encarregado pelo chefe de Polícia, Xavier de Toledo, de preparar um Regulamento sobre a Prostituiçáo em que procurava estabelecer as regras para as relações da polícia com essa prática (que não entrou em vigor, mas deu origem ao artigo mencionado). Em agosto de 1928, depois de Motta publicar no jornal Correio Paulistano algumas passagens de sua atuação na Polícia como delegado, Fausto Ferraz, que foi delegado na mesma época e alvo de algumas críticas de Motta, comenta que o tal Regulamento era uma "obra prima de bobagens que serviu de moto para gostosas brincadeiras e que ficara no papel escrito pelo dr. Mottinha."(DIÁRIO NACIONAL, 1928, p. 10). Fausto zomba do que ele e Antônio de Godoy (também policial) chamavam na época de "Código Nazianzeno" com proibiçóes das prostitutas de ficarem debruçadas nas janelas, que visava interditar o convite das mulheres aos clientes, entre outras medidas. 
Tais rusgas, no final da década de 1920, seriam retomadas pelos jornais. De um lado, Candido Motta publicando suas "memórias" no Correio Paulistano e, de outro, Fausto Ferraz no Diário Nacional (de oposição ao PRP) trocando farpas e acusaçóes mútuas sobre acontecimentos que se passaram em 1896, quando ambos estavam na condição de delegados de polícia na Capital, um como $2^{\circ}$ delegado e outro como $5^{\circ}$, respectivamente. Motta sugere que Fausto teria colocado agentes secretos para segui-lo e Fausto encerra um de seus artigos chamando-o de visionário perigoso e recomendando a Motta "Procurar um psiquiatra que possa curar as enfermidades mentais que o atormentam; conselho de quem, apesar de ter sido vítima de uma tentativa de crime falho, manejado pela ponta enferrujada da pena de V. Exa ${ }^{a}$, deseja o restabelecimento de sua preciosa saúde." (DIÁRIO NACIONAL, 1928, p. 4).

\section{O concurso na Faculdade de Direito}

Como já afirmado, em 1897, Candido Motta fez concurso e se tornou lente substituto na cadeira de Direito Penal na mesma faculdade (CORREIO PAULISTANO, 1897, p. 1). Em 1927, relembra aspectos desse concurso nos artigos publicados no jornal Correio Paulistano intitulados "Por que e como me tornei professor da Faculdade de Direito de São Paulo". Menciona que, quando era estudante, durante o curso de Direito, embora nele fosse "figura apagada", havia sempre dado preferência ao Direito Penal e afirmava que, em seus estudos, "sempre tive indizível atração pelas teorias da nova escola italiana de criminologia”. Essa identificação com tais teorias e suas atuaçóes no tribunal do júri é que teriam levado, um dia, Severino Prestes a se aproximar de Candido Motta e pedir-lhe para concorrer à cátedra de substituto dele na Faculdade de Direito. Teria dito Prestes para Motta: "Pertencemos à mesma escola e será para mim muito mais agradável que o meu substituto seja um meu continuador e não um antagonista." (CORREIO PALISTANO, 1927, p. 2). Isso o teria motivado a assumir o cargo de delegado de polícia, no qual poderia desenvolver seus estudos sobre os criminosos, e concorrer ao cargo de professor substituto. A banca foi constituída por Almeida Nogueira, Oliveira Escorel, Pedro Lessa, Brasílio dos Santos e Brasílio Machado. Motta descreve as polêmicas ocorridas no transcorrer da arguiçáo, sobretudo com Pedro Lessa e Brasílio dos Santos 
acerca de temas ligados às ideias da Nova Escola (CORREIO PAULISTANO, 1927, p. 2).

Motta foi candidato único e a congregação o aprovou para o cargo de substituto. Com certo tom de queixa, lembra Candido Motta que teve que ficar 10 anos como substituto, ainda que tivessem morrido os dois professores que ocupavam aquela cátedra, e só com a morte de Oliveira Escorel é que passou a catedrático (CORREIO PAULISTANO, 1927, p. 2).

É certo que, mesmo na condição de professor substituto, Motta se firmou no campo intelectual e sobretudo político. Em novembro de 1902, Candido Motta, Paulo Egídio, Ezequiel Ramos Jr. e Wenceslau de Queiroz passaram a constituir a comissão da revista da Sociedade de Psicologia de S. Paulo, que passava a ser dirigida por Almeida Nogueira. Ao noticiar a realização de assembleia geral dessa sociedade, foram propostos como sócios correspondentes Lombroso, Nina Rodrigues, Julio Xavier de Matos, entre outros (O COMMERCIO DE SÃO PAULO, 1902, p. 2).

A articulação de Candido Motta com os principais nomes no campo da Criminologia positiva também fica evidente quando da passagem de Nina Rodrigues por São Paulo, em 1903. Nina esteve na Faculdade de Direito e visitou diversas instituiçóes, como o Hospício do Juqueri e a Escola Politécnica. Quando da visita à Santa Casa e à Repartição Central de Polícia, Nina Rodrigues foi acompanhado por Candido Motta, Paulo Egídio, Alcântara Machado, todos nomes de destaque em São Paulo na difusão das ideias de Lombroso (CORREIO PAULISTANO, 1902, p. 3; O COMMERCIO DE SÃO PAULO, 1902, p. 2).

Dois eventos evidenciam o prestígio que Nina Rodrigues tinha em São Paulo com os intelectuais e também a proximidade com Candido Motta. O primeiro deles foi a aceitação de Nina Rodrigues como "sócio correspondente” do Instituto Histórico e Geográfico de São Paulo. Numa sessão do Instituto, presidida por Duarte de Azevedo, foi "Aceito sócio correspondente do Instituto o dr. Nina Rodrigues, que achando-se na sala de espera, entra acompanhado dos sócios Candido Motta e [Nogueira?] Jaguaribe, nomeados para recebê-lo." (CORREIO PAULISTANO, 1903, p. 3) ${ }^{10}$.

10 Sobre Nina Rodrigues ver: CORREA (1982). 
O segundo evento foi um jantar oferecido a Nina Rodrigues por médicos e advogados de São Paulo. Além desses profissionais, estiveram presentes muitos políticos. O discurso de saudação dos juristas foi proferido por Brasílio Machado. A saudação dos médicos seria do dr. Arnaldo Vieira de Carvalho, que não pôde estar presente. Coube então a Candido Motta fazer uma saudação a Nina em nome dos médicos (O COMMERCIO DE SÃO PAULO, 1908, p. 2) $)^{11}$.

Em 1908, Motta firma sua condição de professor na Faculdade de Direito: "Por decreto do governo, de ontem datado, foi nomeado lente catedrático de Direito Criminal da Faculdade de Direito o substituto dr. Candido N. Motta na vaga do dr. Oliveira Escorel." (O COMMERCIO DE SÃO PAULO, 1908, p. 2).

Um dos momentos mais expressivos da trajetória de Candido Motta como "defensor da escola positiva" ocorreu igualmente em 1908, quando Enrico Ferri esteve no Brasil, a caminho de Buenos Aires. Candido Motta já era lente catedrático na Faculdade de Direito e ali organizou uma comitiva de alunos para recepcionar, em Santos, Enrico Ferri.

Ao se tomar pelas notícias da imprensa da época, a chegada de Ferri foi um acontecimento que mobilizou "milhares" de pessoas. Dois trens ("repletos de comissóes de sociedades, lentes, estudantes, representantes da imprensa e muitos particulares, admiradores do ilustre cientista italiano." (O COMMERCIO DE SÃO PAULO, 1908, p. 1) partiram de São Paulo logo pela manhã para a recepção, em Santos. Candido Motta e vários alunos foram receber Enrico Ferri no próprio navio. Centenas de pessoas estariam no porto para saudar o professor, com os alunos da Faculdade de Direito fazendo saudaçóes e discursos para Ferri ainda em Santos. No mesmo dia, Ferri veio de trem para São Paulo e na Estação da Luz teria ocorrido nova recepção, com muitas pessoas. Ferri fez um pequeno discurso e foi "delirantemente aclamado pelo povo." (O COMMERCIO DE SÃO PAULO, 1908, p. 2).

Foi Candido Motta quem acompanhou Ferri na visita ao presidente do Estado e aos secretários da Justiça, Agricultura, Fazenda e Interior

II Segundo o jornal, Candido Motta teria saudado em seu discurso "a união das classes dos médicos e dos juristas". 
(O COMMERCIO DE SÃO PAULO, 1908, p. 1), além de recepcioná-lo na Faculdade de Direito (O COMMERCIO DE SÃO PAULO, 1908, p. 3). Não deve ter sido uma mera coincidência que a passagem de Ferri por Sáo Paulo tenha mobilizado membros das elites de Sáo Paulo para a criação de uma sociedade promotora da regeneração dos encarcerados. Não se sabe quem teria instigado essa iniciativa, mas atenderam a esse chamado senhoras das elites: "d. Lucila Mesquita, d. Maria Lydia de Souza Campos, d. Ismenia de Azevedo Cardoso de Almeida, d. Amélia de Creu Lisboa, d. Ercília Vaz do Amaral, d. Branca Leite Moraes de Araújo, d. Vicentina Pugliesi Carbone, d. Maria Pinotti Gamba, d. Marina Crespi”. E, dentre os homens, a comissão para a organização daquela sociedade contava com: "Dr. Julio de Mesquita, Dr. Carlos de Campos, Dr. Candido Motta, José Maria Lisboa, Vitaliano Rotellini, Bartolo Belli." (O COMMERCIO DE SÃO PAULO, 1908, p. 3).

No final do ano de 1908, Candido Motta foi representar o Brasil no Congresso Científico Latino-americano que seria realizado no Chile. Para sua participação nesse evento, Candido Motta produziu a obra Menores delinquentes e seu tratamento no Estado de Sáo Paulo, na qual procurava discutir a situação dos jovens criminosos no Estado de São Paulo e sugerir medidas novas ao seu tratamento pelas instâncias jurídico-penais. As formulaçóes contidas nesse trabalho em parte se relacionam com as ideias desenvolvidas na Classificação dos Criminosos.

Mais um exemplo das articulaçóes de Candido Motta no terreno intelectual se dá também em 1909. Uma notícia no jornal O Commercio de São Paulo referia-se ao lançamento de uma revista científica no Ceará por um "homem de ciência", Soriano de Albuquerque, que era professor da Escola Livre de Direito de Fortaleza. A revista trimestral tinha por título Revista Brasileira de Sociologia. Já contaria com um representante na Europa (professor Ladislau Thot, de Budapest) com trabalhos na área da Criminologia. A lista dos "colaboradores já convidados", por sua vez, envolvia: "Clóvis Bevilacqua, Araripe Jr., Pedro Lessa, Afonso Celso, Sílvio Romero, Euclides da Cunha, Aurelino Leal, Brasílio Machado, Alberto Seabra, Veiga Filho, Horácio de Carvalho, Reynaldo Porchat, J. Vampré e, obviamente, Candido Motta" (O COMMERCIO DE SÃO PAULO, 1909, p. 1). 
É a partir dessas produções e iniciativas que Motta será reconhecido, mesmo décadas depois, como "apóstolo" da Nova Escola, nas palavras de Vampré, em discurso de saudação aos novos professores eméritos, titulados no dia 11 de agosto de 1942:

Um corajoso e tenaz partidário da Escola Positiva de Direito Criminal, cujos progressos seguiu atento até o último lampejo, numa laboriosa vida que foi um apostolado de fé doutrinária, de convicções científicas radicadas, exemplo e lustre de uma geração inteira. (REVISTA DA FACULDADE DE DIREITO DE SÃO PAULO, 1942, p. I6I).

E novamente Noé de Azevedo, no texto sobre a produção científica de Motta, chamava a atenção para a "ousadia" de Motta ao defender, no concurso para substituir o penalista Severino Prestes em 1897, contando apenas 27 anos, a tese Classificação dos Criminosos, inspirada nas ideias criminológicas, pouco divulgadas na instituição à época.

De fato, para Cândido Motta, assim como para muitos simpatizantes das ideias de Lombroso, tratava-se de uma postura militante de divulgação das novas ideias, embora os resultados obtidos, em termos de aprovação de propostas legais e institucionais, sempre tenham sido muito mais modestos, mesmo que, em torno dessas ideias, certo empreendimento intelectual biodeterminista - voltado para a compreensão do homem em geral e do homem criminoso, em particular - tenha efetivamente se consolidado e avançado até os anos de 1940 do século XX, ao menos em São Paulo (ALVAREZ, 2003; FERLA, 2005).

Em sua trajetória política, dois projetos defendidos por Cândido Motta estarão mais diretamente sustentados pelas ideias da Nova Escola: o do Instituto Disciplinar para Menores Delinquentes, criado em 1902, e o da Penitenciária do Estado, inaugurada em 1920 (MOTTA, 1909; ALVAREZ, 2003; SALLA, 1999). Sua atuação política, no entanto, irá muito além do "apostolado" criminológico.

\section{A trajetória política de Candido Motta}

Depois de ocupar o cargo de promotor público, até 1896, é gradativa a inserção de Candido Motta na política. Começa com a sua nomeação, ainda em 1896, para o cargo de $2^{\circ}$ delegado de polícia na cidade de São 
Paulo. A escolha era de natureza eminentemente política, uma vez que não havia até então uma carreira de delegado. O convite partiu do Chefe de Polícia José Xavier de Toledo. Embora não tenha permanecido por muito tempo nesse cargo, apenas dez meses, ele foi importante, como já visto, para acentuar no meio político a sua condição de "homem de ciência" que recorria à Antropologia Criminal para a execução de suas tarefas. Sua tese A Classificação dos Criminosos teria sido produzida nesse período, quando estava se preparando para o concurso na Faculdade de Direito e fazia visitas às prisóes, como mencionado acima, para estudar os presos. Defendia o uso da antropometria e da fotografia como recursos para identificação dos criminosos reincidentes. Para tanto, conseguiu do chefe de polícia a importação de uma máquina chamada tachy-antropometro de Anfosso que seria um dos mais avançados recursos para a identificaçáo dos indivíduos na época (CORREIO PAULISTANO, 1928, p. 2). ${ }^{12}$

A sua condução ao cargo de professor substituto na Faculdade de Direito, em 1897, vai favorecer ainda mais o seu percurso no mundo da política. Em 1898, foi eleito deputado estadual para duas legislaturas seguidas (4a Legislatura, 1898-1900, e 5a Legislatura, 1901-1903).

Trouxe Candido Motta, em alguns de seus discursos pronunciados nas sessóes legislativas de 15 de junho e 30 de agosto de 1898, na Câmara, as influências da Antropologia Criminal e das ideias de Lombroso e seus seguidores sobre o júri. Entendia ser essa instituição popular formada por ignorantes acerca dos assuntos penais, ineficiente e injusta do ponto de vista jurídico. A lógica que preside sua argumentação é a de que as decisões do júri deveriam ser submetidas a fundamentos técnicos, jurídicos e científicos, e não a uma simples vontade popular.

Mas como instituição judiciária, como instituição repressiva, é incontestável que o júri é o que de mais ineficaz e mais fraco temos e que, portanto, deve ser eliminado do corpo da nossa organização judiciária como um mecanismo imprestável! [...] sendo os jurados

12 É o próprio Candido Motta quem relembra esses fatos numa matéria por ele assinada, publicada no dia II de janeiro de 1928 no jornal Correio Paulistano, na coluna Águas Passadas... Recordações. Trazia por título A Polícia de S. Paulo em 1896; suas instalações; organização; pessoal. Luigi Anfosso foi o inventor desse aparelho de medição rápida do corpo dos criminosos e teria sido um precursor, relativamente pouco conhecido, de Alphonse Bertillon. 
escolhidos indistintamente pela sorte cega de todas as classes do povo, não podem representar outra coisa senão a qualidade dominante deste, isto é, a ignorância. (MOTTA, 1898a, p. 199-200).

No entanto, a sua proposta de uma reformulação do júri não teve continuidade. Foi ainda, nesse período, o proponente de um projeto de criação do Instituto Disciplinar para menores, como citado. Como se tem aqui argumentado, por muito tempo Candido Motta vai ser lembrado como uma referência no campo das concepçóes sobre o tratamento dos "menores". ${ }^{3}$ $\mathrm{O}$ instituto correcional não deveria, para Motta, ser entendido como uma prisão tradicional, mas sim como um baluarte do tratamento científico da criminalidade. Por essa razão, sua direção deveria ser confiada ou a um jurista ou a um médico versado nos conhecimentos da Antropologia Criminal. A função primordial do instituto era a correção dos indivíduos considerados moralmente enfraquecidos. Tanto é assim que, no projeto original, o nome proposto para o instituto afastava qualquer associação com os institutos de sequestro tradicionais, Instituto Educativo Paulista.

O projeto de Motta, apesar de aprovado, sofreu emendas significativas no Senado paulista. A versão final do projeto ganhou estatuto de lei (Lei no 844), aprovada em 10 de outubro de 1902, e foi regulamentada pelo Decreto $n^{\circ} 1079$, de 30 de dezembro do mesmo ano, que acabou por criar o Instituto Disciplinar, como ficou sendo chamado o instituto correcional proposto por Candido Motta. Essa proposta de um reformatório para menores bem como a reforma penitenciária, com a qual Motta vai se envolver posteriormente, davam continuidade ao que o Senador estadual Paulo Egídio estava propondo desde a década de 1890 (SALLA; ALVAREZ, 2000).

Mas esse foi igualmente um período em que Candido Motta marcou presença no cenário propriamente político, sobretudo no interior do PRP, em 1901 e 1902, quando integrou uma dissidência do partido liderada por Prudente de Moraes, dissidência essa que se atribuía a tarefa de defender os valores republicanos. $\mathrm{O}$ jornal $O$ Combate, que viria a fazer duras críticas a Candido Motta quando foi secretário da Agricultura, de 1916 a

13 Candido Motta Filho será, de certa forma, um herdeiro político desse "patrimônio" institucional em torno do Instituto Disciplinar. Não só produziu obra sobre a menoridade $(1998,1935)$ como foi diretor daquele instituto e depois do Serviço Social de Menores nas décadas de 1930 e 1940. 
1920, menciona que ele era considerado, ao lado de Prudente de Moraes, Alfredo Pujol, Júlio Mesquita, Antônio Mercado, Moraes Barros, Batista Pereira, Celso Garcia, Edmundo Fonseca, Guimarães Júnior, “[...] uma das figuras mais brilhantes do pequeno, mas coeso partido que a morte de Prudente logo esfacelara." (O COMBATE, 1920, p. 1) ${ }^{14}$. Esse grupo chegou a cogitar a participação nas eleições presidenciais com nomes como o de Quintino Bocaiuva e Assis Brasil. Por algum tempo, opositores de Candido Motta se lembrariam dele como dissidente, e de sua crítica à política então predominante em São Paulo, que o teria levado a afirmar que se vivia no começo do século sob uma "oligarquia imoral e perigosa" (O COMBATE, 1917, p. 2). ${ }^{15}$

Tais conflitos no âmbito do partido hegemônico, que era o PRP, no entanto, não parecem ter danificado a sua carreira política. Depois desses dois mandatos iniciais na Câmara dos Deputados, Candido Motta foi eleito para a Câmara de Vereadores de São Paulo, para a Legislatura 1905-1907. Ali, como vereador, integrou a Comissão de Justiça. Motta participou intensamente das atividades da Câmara, em todas as questôes que ocupavam essa casa. Chegou a ter algumas discussóes com Antônio Prado, que já havia sido prefeito, sobre alargamento de ruas e melhoria das condiçóes de circulação de veículos no centro. Mas debateu também a questão da autorização de jogos e divertimentos na Penha, desapropriaçóes, embelezamento da cidade etc.

Volta a ser deputado estadual para a $7^{\text {a }}$ Legislatura (1907-1909). Em 1909, Candido Motta integrou uma comissão encarregada de escolher o projeto da nova penitenciária para o estado de São Paulo. A comissão era presidida por Motta, tendo como secretário Ignacio Wallace da Gama Cochrane e ainda como membros Mauro Alvaro de Souza Camargo, José Van Humbeeck e Pedro de Mello Souza Jr. Num breve artigo, Motta (1910) apresenta os projetos que foram encaminhados e as razóes que fizeram com que a escolha recaísse sobre o projeto de Samuel das Neves, denominado

14 As fortunas na Secretaria da Agricultura. No governo Bernardino de Campos. Os Mottas de 1901.

15 Esse mesmo jornal usava sarcasticamente variações dessa expressão que Motta teria pronunciado contra a oligarquia paulista como "crise no Sindicato de empregos, na oligarquia imoral e perigosa sob cujo guante vivemos". 
Laboravi Fidenter. Apresentava uma proposta arquitetônica que a comissão considerou mais adequada quanto à disposição dos pavilhóes, oficinas etc. Os defeitos no projeto seriam de pequena monta, facilmente sanáveis, e os custos eram elevados, mas aceitáveis (SALLA, 1999). O fato de Motta ter assumido a presidência dessa comissão não era um mero acaso. Além de sua projeção política como parlamentar, que se consolidava, era no âmbito acadêmico o professor que acumulava um amplo conhecimento das questôes penais, das formas de tratamento penitenciário e mantinha interlocução com nomes de projeção no plano nacional e internacional. Dominava, ainda, o conhecimento atualizado dos projetos arquitetônicos para as prisóes e dos debates travados na esfera internacional nos congressos penitenciários.

Ainda em 1909, inicia um período como parlamentar no plano federal, sendo eleito deputado federal sucessivamente para as legislaturas de 19091911, 1912-1914 e 1915-1917. Porém, esse último mandato foi interrompido com a sua renúncia, em 1916, para assumir, em São Paulo, a Secretaria da Agricultura, Comércio e Obras na qual permaneceu até 1920.

Mesmo quando se tornou deputado federal, não deixou de atuar em São Paulo como advogado, como vinha fazendo desde que se tornou bacharel em Direito. Sua atividade política continuou intensa em São Paulo, circulando pelas homenagens, pelos almoços e reunióes com os círculos mais elevados do governo e do PRP. Ao lado de seu prestígio como político, por vezes ainda ganhava novamente destaque na imprensa da época como uma das mais importantes expressóes da Antropologia Criminal, como ocorreu em junho de 1914, quando recebeu uma carta do professor Jules Rickl de Bellye pedindo a colaboração de Candido Motta para o $8^{\circ}$ Congresso Internacional de Antropologia Criminal que seria realizado em Budapest ainda em setembro de 1914. Com o título de Uma distinção honrosa o jornal Correio Paulistano transcreveu parte daquela carta, na qual o presidente da comissão organizadora pedia a Candido Motta, como:

[...] especialista que sois dos mais eminentes de vossa pátria, o vosso precioso concurso tanto para os preparativos do Congresso como para a sua propaganda. Por conseguinte, ficaria infinitamente grato se consentísseis em despertar o interesse dos círculos jurídicos e médicos, assim como os das autoridades e periódicos interessados em favor do nosso 
Congresso, convidando-os da vossa parte também para tomar parte no Congresso. (CORREIO PAULISTANO, 1914, p. 5).

E além de servir de referência para a divulgação do evento no Brasil, Candido Motta também estava sendo convidado para integrar o "Comitê", que seria eleito em Budapest, para a organização dos futuros congressos.

Motta foi secretário da Agricultura no governo do presidente do estado, Altino Arantes (1916-1920). Pode-se afirmar que foi um dos momentos de maior projeção na sua trajetória política. A secretaria que ocupou (Agricultura, Comércio e Obras Públicas) era, sem dúvida, uma das mais importantes na dinâmica política e econômica do Estado. Mobilizava recursos para a principal atividade econômica, o café, regulava os fluxos migratórios, apoiava outras atividades agrícolas, dispunha dos recursos para as obras públicas, transportes de carga, edificaçôes públicas em geral. Enfim, tinha uma atuação ampla e mobilizava articulações políticas e econômicas com os poderes locais, com a esfera federal e com empresas privadas, especialmente no setor ferroviário.

Se a sua condição de secretário de uma das mais importantes pastas no governo do estado de São Paulo lhe adensava prestígio, poder e status político, o contexto no qual se desenvolveu sua administração foi complexo e desafiador. A Primeira Guerra Mundial (1914-1918) desarticulara os fluxos internacionais de comércio, ao mesmo tempo em que havia uma interrupção de importaçóes de produtos que supriam o mercado interno, as oportunidades de exportação de gêneros alimentícios trouxeram o fantasma e a crise da escassez de alimentos, a alta do custo de vida e as tensóes sociais que agitaram muitas cidades naquele período. Motta tentou contornar alguns desses problemas desenvolvendo campanhas para o aumento da produção de gêneros alimentícios, da produção de cereais, ampliação da produção pecuária, ampliação da rede de transporte por meio de estradas de rodagem etc.

Agricultores reclamavam dos serviços das empresas ferroviárias que não proporcionavam as condiçóes para o armazenamento e o escoamento da produçáo. Candido Motta foi acusado de ser conivente com o aumento de tarifas sobre o frete das cargas dessas empresas à revelia dos contratos vigentes, de não cobrar delas os serviços demandados pelos agricultores e de se beneficiar de mimos proporcionados por uma dessas companhias (a 
Sorocabana). Ao mesmo tempo, foi submetido a severas críticas por ter recorrido ao nepotismo, tendo colocado vários parentes na administração pública, inclusive seu filho, Candido Motta Filho, que foi oficial de gabinete da Secretaria da Agricultura durante quase toda a sua administração. ${ }^{16}$

Foi ainda alvo de muitas acusaçôes, de mau uso do dinheiro público nas obras de captação de água de Cotia para a capital e também de ter realizado obras em suas propriedades particulares com recursos financeiros públicos.

Para tumultuar ainda mais sua administração, Motta moveu um desastroso processo por injúrias impressas contra o jornalista Nereu Rangel Pestana, editor responsável do jornal O Combate. Nereu foi condenado, em primeira instância, mas o processo foi anulado no Tribunal de Justiça e vários jornais expuseram publicamente a disputa, trazendo certo desgaste à figura de Candido Motta, pois movera o processo não como secretário (e havia acusaçóes do jornal $O$ Combate por uso indevido de recursos públicos nessa condição), mas como professor da Faculdade de Direito. O desgaste foi considerável e Candido Motta chegou a pedir demissão do cargo de secretário assim que saiu a decisão do judicial anulando a condenação de Nereu Rangel Pestana. Porém, Altino Arantes náo aceitou o pedido (O COMBATE, 1917, p. 1; A GAZETA, 1917, p. 1).

A crise no sistema de transporte ferroviário fez com que se desse uma ampla mobilização em favor de investimentos nas estradas de rodagem. Candido Motta presidiu pelo menos dois congressos paulistas (um em 1917, outro em 1919) que reuniam políticos de prestígio, como Washington Luís e Antônio Prado, que integravam a Associação Permanente de Estradas de Rodagem. Tanto no primeiro como no segundo Congresso de Estradas de Rodagem, discutiu-se a utilização de sentenciados nos trabalhos de abertura e manutenção das estradas ${ }^{17}$.

16 Além de seu filho, Cassio Motta era médico do Hospício do Juqueri e consta que estava sendo indicado por seu irmão, Candido Motta, para um cargo num hospício que estava para se instalar em Jacareí. Depois conseguiu o cargo de diretor do Instituto de Veterinária, que era subordinado à Secretaria da Agricultura. Maximiano Motta, funcionário da Secretaria do Interior, era sobrinho de Candido Motta. Arthur Motta trabalhava na Secretaria da Agricultura como diretor da Repartição de Águas e Esgotos. Em 1914, faleceu João Nazianzeno Nogueira da Motta, diretor do Instituto Disciplinar e irmão de Candido Motta.

17 O uso de presos nas obras de estradas de rodagem vinha desde a aprovação da Lei n ${ }^{\circ}$ 1406, de 20 de dezembro de 1913. Presos começaram a ser usados inicialmente na ligação de São Paulo a Jundiaí (SALLA, 1999). 
Depois de ocupar esse cargo, como secretário da Agricultura, Candido Motta foi eleito para o senado estadual para o período 1922-1930. Em 1922, no entanto, ficou muito doente, chegando mesmo a se especular, caso viesse a morrer, como seria sua substituição no Senado ${ }^{18}$. Mesmo assim assume suas atividades no final daquele ano. Sua atuação nessa casa, no entanto, será bastante discreta e nunca se distanciará de suas alianças políticas. Exemplo disso se apresenta no final dos anos de 1920, quando as tensóes políticas e as hostilidades com a hegemonia paulista se elevaram. Motta, em 23 de setembro de 1929, trata em um discurso das tensóes da sucessão presidencial. Critica os movimentos de oposição aos paulistas e marca sua posição no debate em favor da continuidade dos esquemas políticos tradicionais da República. Segundo Motta, a Aliança Liberal, que entáo se opunha ao candidato paulista Júlio Prestes, náo passava de um agrupamento de pessoas com interesses particulares sem nenhum princípio. Via a oposição ao candidato do PRP como resistência ao próprio estado de São Paulo. E, no melhor estilo dos líderes do PRP, atribuía as tensões ao reconhecimento da grandeza paulista por parte de certos agrupamentos políticos de outras regióes. Elogiando as virtudes de São Paulo por meio do resgate dos mitos do bandeirismo e da República, Motta caracteriza o estado como a principal porção do território nacional, responsável tanto pelo crescimento territorial do País como por sua modernização política.

Embora sua atividade parlamentar na década de 1920 no Senado tenha sido discreta, seu nome era ali constantemente lembrado, fosse na questão do Instituto Disciplinar, fosse também na condição de membro da comissão que escolheu o projeto da Penitenciária do Estado, que entrou em funcionamento em 1920. Em matéria de página inteira sobre o Presídio do Carandiru (Penitenciária do Estado), lembrava o repórter, Honorio de Sylos, a figura de Candido Motta na formação da Comissão julgadora dos projetos em 1910. O repórter foi até a casa onde residia Candido Motta para entrevistá-lo sobre a comissão e a escolha do projeto da Penitenciária do Estado. Naquela oportunidade, Candido Motta demonstrou ter conhecimento apurado e atualizado sobre os modelos arquitetônicos,

18 O próprio filho de Candido Motta, no seu liuro de memórias, menciona a gravidade de seu estado de saúde. Para saber mais, ver: MOTTA FILHO (1972, p. 26-28). 
as necessidades de disciplina, trabalho e instrução, os modelos luxuosos e de palacetes que deveriam ser evitados. Lamentou que a maior parte dos projetos apresentados, em 1910, fosse no modelo radiado, o que já teria mostrado inconvenientes nos outros países. Apesar de ter sido aprovado um modelo de penitenciária industrial, Candido Motta (talvez por arrependimento ou para mostrar afinidade com as ideias em voga nos anos 1920) destacou o valor do trabalho ao ar livre, citando Ferri (CORREIO PAULISTANO), 1927, p. 7).

Quando dos debates na Câmara dos Deputados de São Paulo em torno da criação do juizado privativo de menores, Candido Motta foi lembrado mais uma vez e citado pelos parlamentares, como Roberto Moreira e Armando Prado, principalmente o seu estudo Menores e delinquentes $e$ seu tratamento no estado de S. Paulo (CORREIO PAULISTANO, 1924, p. 6-7). Até 1930, permaneceu como senador, e como professor da Faculdade de Direito até $1937 .{ }^{19}$

O jornal Diário Nacional, de oposição ao PRP, logo depois da chegada ao poder de Getúlio Vargas, destacou a oposição que os alunos da Faculdade fizeram à tentativa de Candido Motta assumir a direçáo por ser o professor mais velho:

O ex-senador perrepista, sr. Candido Motta, professor da Faculdade de Direito, apesar de saber o professor João Arruda na direção daquele estabelecimento de ensino desde o dia da vitória revolucionária, compareceu ontem ao velho casarão do largo São Francisco e, na qualidade de lente mais velho, chamou a si a direção da casa que formou o espírito liberal de Ruy Barbosa.

O professor João Arruda não teve dúvida alguma em passar-lhe o cargo, mas por isso não estiveram numerosos alunos.

É assim que na própria sala da diretoria o sr. Candido Motta foi interpelado sobre se não se sentia acanhado em ocupar um posto que lhe ficava mal depois da era revolucionária e ainda mais depois de nele ter sido investido o respeitável professor João Arruda.

O lente de Direito Penal respondeu que ignorava o fato, apesar de toda a imprensa de São Paulo haver noticiado que o professor João Arruda era o diretor desde o momento

19 Há certa controvérsia sobre a data de seu afastamento definitivo das atividades de professor. São muitas as licenças que tirou por razões de saúde que dificultam a definição com precisão dessa data, se 1934, 1936 ou mesmo 1937. Certo é que Motta escreve uma carta de despedida que é publicada em 1937 (MOTTA, 1937). 
que o sr. Pinto Ferraz, também ex-senador perrepista, abandonara o cargo. E não deu atenção...

Não se conformaram os alunos democratas e dirigiram ao dr. Getúlio Vargas, chefe supremo da Revolução Brasileira, o seguinte telegrama: "Alunos da Faculdade de Direito de São Paulo contra posse novo diretor Candido Motta, ex-senador perrepista, pedem nomeação dr. João Arruda que já havia assumido direção da Faculdade”. (DIÁRIO NACIONAL, 1960, p. 2).

Naquele momento, Candido Motta parece ter sido mantido na condição de vice-diretor, uma vez que assim é mencionado quando preside uma conferência ministrada da Faculdade de Direito por A. A. de Covello em agosto de 1931 (DIÁRIO NACIONAL, 1931, p. 5). Viria, no entanto, a efetivamente ocupar a direção da Faculdade de Direito em abril de 1935, depois da saída do professor Raphael Sampaio, então diretor. O Conselho Técnico Administrativo da Faculdade elegeu-o para a direção (CORREIO PAULISTANO, 1945, p. 4).

O prestígio político de Candido Motta junto aos alunos foi colocado em questão igualmente em abril de 1936, quando o Centro Acadêmico XI de Agosto estava organizando o trote dos calouros (cabeça raspada, interdição de acesso ao espaço de snooker do "Club XI de Agosto"). Antes de decretar como seria o trote, foram apresentados os "considerandos", um deles referia-se a Motta: "Atendendo a que, com o afastamento do sábio mestre dr. Candido Motta, a Faculdade perdeu um insubstituível professor de Paleontologia de Direito Penal." (CORREIO PAULISTANO, 1936, p. 9). O grande "apóstolo" dos conhecimentos científicos "revolucionários" da Antropologia Criminal era agora ridicularizado pelos estudantes do Largo São Francisco como uma relíquia de outros tempos...

Mas, mesmo nos anos de 1930, seus vínculos políticos e sua condição de referência acadêmica entre seus pares sobre a questão penal o levaram a ser indicado para participar, como delegado pelo estado de São Paulo, na Conferência Penal e Penitenciária que foi realizada em junho de 1930. Participaram também, por São Paulo, A. C. Pacheco e Silva e Márcio Munhoz. Motta fez aí uma conferência sobre o trabalho dos sentenciados (A GAZETA, 1930, p. 14).

De 1928 a 1942, quando se deu sua morte, a presidência do Conselho Penitenciário foi a principal atividade pública de Candido Motta, dando 
continuidade ao seu envolvimento com questôes penais. Em meio a suas atividades como senador, em 1928, Motta havia sido nomeado presidente do Conselho Penitenciário que foi constituído em São Paulo ${ }^{20}$ com base no Decreto $\mathrm{n}^{\circ} .4 .365$, de 31 de janeiro daquele mesmo ano. O Conselho era formado para atender ao Decreto Federal $n^{\circ} .16 .685$, de 6 de novembro de 1924, que regulava a questão do livramento condicional dos sentenciados. A presidência do Conselho tinha então considerável prestígio, o que pode ser constatado pela composição desse órgão, que tinha como membros nomes destacados no campo da Medicina e do Direito: Alcântara Machado, professor de Medicina Legal da Faculdade de Direito; Flamínio Fávero, professor de Medicina Legal da Faculdade de Medicina; A. C. Pacheco e Silva, diretor do Hospital do Juqueri; e Alfredo Pujol, advogado.

A participação no Conselho Penitenciário mostra como sua filiação às ideias da Antropologia Criminal o acompanhou até o final de sua trajetória. Tanto que, no texto em homenagem a Cândido Motta em 1942, já citado, Noé Azevedo relembra o momento heroico de seu ingresso na Faculdade de Direito:

$\mathrm{Na}$ ocasião em que fez concurso, ainda dominavam nesta casa as concepções metafísicas do direito, apesar do intenso trabalho de arejamento iniciado pelo grande PEDRO LESSA. Constituiu, portanto, uma verdadeira ousadia a apresentação de um estudo vasado no estilo revolucionário de FERRI, LOMBROSO, GAROFALO e demais companheiros do positivismo. Com desassombro, compareceu CANDIDO MOTTA perante a Congregação, em 1897, com a sua "Classificação dos Criminosos" [...] (AZEVEDO, 1942, p. 176).

\section{Considerações finais}

O objetivo da presente discussão consistiu em apresentar, de forma ainda exploratória, a trajetória de formação e de atuação de Candido Motta, tendo em vista o possível aprofundamento da análise das mudanças ocorridas no "bacharelismo liberal" em São Paulo na virada do século XIX para as primeiras décadas do século XX. Mesmo que em termos de origem social e formação acadêmica Motta possa ser visto como mais um membro

20 Em 08 de fevereiro de 1928, o jornal A Gazeta (p. I) trazia uma nota sobre a composição do Conselho Penitenciário: "Liuramento Condicional. O Conselho Penitenciário do Estado - como ficou ele constituído". 
da classe dirigente em São Paulo na Primeira República (MICELI, 1979), aspectos de sua trajetória intelectual e política chamam a atenção. Sua militância em favor da "Nova Escola Penal" contribuiu para a construção de sua reputação como "cientista" no interior do campo do Direito Penal, ao viabilizar seu ingresso na Faculdade de Direito. O prestígio acadêmico assim obtido servirá permanentemente de esteio para sua carreira política que atingirá o ápice provavelmente com o cargo de secretário da Agricultura, como visto.

Aproximadamente uma geração antes, Paulo Egídio de Oliveira Carvalho (1842-1906), advogado e político, embora mais consistente em termos acadêmicos, não havia obtido grande sucesso em levar as novas ideias da Criminologia para o interior das Arcadas e sua proposta de reforma penitenciária para o Estado, embasada nas novas ideias da Antropologia e da Sociologia Criminal, igualmente pouco avançara (SALLA; ALVAREZ, 2000). Motta, em contrapartida, obteve sucesso na criação de duas instituições que já apareciam como centrais no "sistema penitenciário" de Paulo Egídio, o Instituto Disciplinar e a Penitenciária do Estado. Boris Fausto considera que o Instituto Disciplinar “[...] não teve o papel preponderante que as autoridades lhe quiseram atribuir, pois abrigou apenas uma dezena de meninos." (FAUSTO, 1984, p. 84), mas não é possível subestimar o papel simbólico da instituição no imaginário das elites da época e também o papel desempenhado na construção do sistema de justiça juvenil no estado e mesmo posteriormente, na década de 1930, como parte do Serviço Social dos Menores, inclusive dirigido pelo "herdeiro", Candido Motta Filho, o mesmo podendo ser afirmado com relação à Penitenciária do Estado (ALVAREZ, 1989; SALLA, 1999).

Pode-se especular que a concorrência crescente de outros "homens de ciência”, sobretudo os médicos, ao longo das primeiras décadas do século XX, tenha paulatinamente eclipsado a militância dos juristas da "Escola Positiva”, inclusive com a posterior consolidação de especializações como a Medicina Legal (ALVAREZ, SALLA; ALVES, 2012). Parece certo que nesse período tanto os médicos como os juristas simpatizantes e disseminadores da Nova Escola Penal tiveram papel relevante no ordenamento das instituições do Estado voltadas para o controle social. Nesse sentido, 
Cândido Motta, em sua atuação ao mesmo tempo intelectual e política, indica os caminhos de certa "modernização" da ordem oligárquica que ainda precisa ser mais bem investigada em suas múltiplas dimensôes.

\section{Fontes consultadas}

Anais da Câmara dos Deputados do Estado de São Paulo (1898-1900; 1907-1909).

Anais do Senado do Estado de São Paulo (1922-1929).

\section{Referências}

ADORNO, S. Os aprendizes do poder - o bacharelismo liberal na política brasileira. Rio de Janeiro: Paz e Terra, 1988.

A GAZETA, de 19 de junho de 1930. <http://bndigital.bn.gov.br/hemeroteca-digital/>. Acesso em: 6 set. 2018.

A GAZETA, de 20 de setembro de 1917.

ALVAREZ, M. C. Bacharéis, Criminologistas e Juristas: saber jurídico e Nova Escola Penal no Brasil. São Paulo: Ibccrim, 2003.

ALVAREZ, M. C. A Criminologia no Brasil ou Como Tratar Desigualmente os Desiguais. Dados Revista de Ciências Sociais, Rio de Janeiro, v. 45, n. 4, p. 677-704, 2002.

ALVAREZ, M. César; SALLA, F; ALVES, Kelly L. Medicina Legal, Criminologia e Puniçáo: aspectos da trajetória intelectual e profissional de Flamínio Fávero (1895-1982). Saúde, Ética \& Justiça, São Paulo, v. 17, n. 2, p. 57-65, 2012.

ARAÚJO, J. V. de. Ensaio de direito penal ou repetiçóes escriptas sobre o Codigo Criminal do Império do Brazil. Recife: Typographia do Jornal do Recife, 1884.

AUGUSTO, C. B.; ORTEGA, F. Nina Rodrigues e a Patologização do Crime no Brasil. Revista de Direito GV, São Paulo, v. 7, n. 1, p. 221-236, jan-jun., 2011.

AZEVEDO, A. Dos tribunaes especiaes para menores delinquentes e como podem ser creados entre nós, São Paulo: Edictores Saraiva e Cia., 1920.

AZEVEDO, N. O professor Candido Motta e sua obra científica. Revista da Faculdade de Direito, São Paulo, v. 38, p. 175-186, 1942.

. Centenário de nascimento de Candido Nazianzeno Nogueira da Motta. Revista da Faculdade de Direito, São Paulo, v. 65, p. 313-328, 1970.

BARRETTO, T. Menores e Loucos e Fundamento do Direito de Punir. Rio de Janeiro: Empresa Gráfica Editora de Paulo Pongetti \& G. Obras Completas, vol. V (Edição do Edição do Estado de Sergipe), 1923. [1884]. 
CANDIDO, A. A Sociologia no Brasil. Revista Tempo Social, São Paulo, v. 18, n. 1, p. 271-301, 2006.

CASALECCHI, J. Ê. O Partido Republicano Paulista: política e poder (1889-1926). São Paulo: Brasiliense, 1987.

CASTRO, F. J. V. de. A Nova Escola Penal. Rio de Janeiro: Domingos de Magalhães, 1894.

CORREA, Mariza. As ilusóes da liberdade: Nina Rodrigues e a Antropologia no Brasil. São Paulo, Tese de Doutoramento em Antropologia, USP, 1982.

CORREIO PAULISTANO, de 12 de janeiro de 1892. Disponível em: <http://bndigital. bn.gov.br/hemeroteca-digital/>. Acesso em: 6 set. 2018.

CORREIO PAULISTANO, de 5 de outubro de 1894.

CORREIO PAULISTANO, de 9 de outubro de 1894.

CORREIO PAULISTANO, de 17 de outubro de 1895.

CORREIO PAULISTANO, de 21 de dezembro de 1895.

CORREIO PAULISTANO, de 20 de março de 1897.

CORREIO PAULISTANO, de 26 de novembro de 1902.

CORREIO PAULISTANO, de 21 de outubro de 1903.

CORREIO PAULISTANO, de 25 de outubro de 1903.

CORREIO PAULISTANO, de 10 de junho de 1914.

CORREIO PAULISTANO, de 21 de dezembro de 1924.

CORREIO PAULISTANO, de 11 de janeiro de 1927.

CORREIO PAULISTANO, de 13 de janeiro de 1927.

CORREIO PAULISTANO, de 14 de janeiro de 1927.

CORREIO PAULISTANO, de 11 de janeiro de 1928.

CORREIO PAULISTANO, de 26 de abril de 1935.

CORREIO PAULISTANO, de 2 de abril de 1936.

CORREIO PAULISTANO, de 7 de julho de 1927.

DIÁRIO NACIONAL, de $1^{\text {o }}$ de agosto de 1928. Disponível em: <http://bndigital. bn.gov.br/hemeroteca-digital/>. Acesso em: 6 set. 2018.

DIÁRIO NACIONAL, de 4 de agosto de 1928.

DIÁRIO NACIONAL, de $1^{\circ}$ de novembro de 1930.

DIÁRIO NACIONAL, de 11 de agosto de 1931. 
DIAS, A. A. T. Arquivos de Ciências, Crimes e Loucuras: Heitor Carrilho e o debate criminológico no Rio de Janeiro entre as décadas de 1920 e 1940. Tese (Doutorado em História das Ciências e da Saúde) - Programa de Pós-Graduação em História das Ciências e da Saúde da Casa de Oswaldo Cruz - Fundação Oswaldo Cruz. Rio de Janeiro, 2015.

FERLA, L. A. C. Feios, sujos e malvados sob medida: do crime ao trabalho, a utopia médica do biodeterminismo em São Paulo (1920-1945). Tese (Doutorado em História). Universidade de São Paulo, 2005.

FOUCAULT, M. Verdade e Poder. In: Microfísica do Poder. Petrópolis: Vozes, 1979.

HERSCHMANN, M. M.; PEREIRA, Carlos Alberto M. (Org.). A invençáo do Brasil moderno: medicina, educação e engenharia nos anos 20-30. Rio de Janeiro, Rocco, 1994.

MACHADO NETO, A. L. História das Idéias Jurídicas no Brasil. São Paulo: Grijalbo/ Edusp, 1969.

MAIO, M. C. A Medicina de Nina Rodrigues: Análise de uma Trajetória Científica. Cadernos de Saúde Pública, Rio de Janeiro, v. 11, n. 2, p. 226-237, abr./jun., 1995.

MICELI, S. Intelectuais e Classe Dirigente no Brasil (1920-1945). Coleção Corpo e Alma do Brasil. São Paulo: Difel, 1979.

MOTTA, C. Prostituição, Polícia de Costumes, Lenocínio. Revista da Faculdade de Direito de São Paulo, São Paulo, v. 5, p. 307-322, 1897.

. Discurso pronunciado na sessão legislativa de 15 de junho de 1898 sobre o projecto que altera algumas disposiçōes da organização judiciária no Estado. Revista da Faculdade de Direito de Sáo Paulo, São Paulo, v. 6, p. 195-236, 1898a.

.. Discurso pronunciado na sessão legislativa de 30 de agosto de 1898 sobre o projecto que altera algumas disposições da organização judiciária no Estado. Revista da Faculdade de Direito de Sáo Paulo, São Paulo, v. 6, p. 236-277, 1898b.

. Sáo Paulo e a República - ainda a grande obra de José de Anchieta. São Paulo: Empresa Gráfica da Revista dos Tribunais, 1935.

. Nova Tormenta. São Paulo: Revista dos Tribunais, 1939.

MOTTA, C. N. N. A justiça criminal na capital do Estado de S. Paulo - Relatorio apresentado ao Dr. Procurador geral em 31 de dezembro de 1894. São Paulo: Typ. a Vapor Espindola, Siqueira \& Comp., 1895.

. Classificação dos criminosos: introdução ao estudo do direito penal. São Paulo, Est. Graphico J.Rossetti, 1925 [1897].

Os menores delinquentes e seu tratamento no Estado de Sáo Paulo, São Paulo, Diário Oficial, 1909. 
. A nova Penitenciária da capital de São Paulo. Relatório da commissão julgadora dos projectos apresentados ao governo do Estado. Sáo Paulo Judiciário, v. 23, n. 89-92, p. 176-195, 1910.

Agora e sempre pela República parlamentar. São Paulo: Associação Cívica Feminina, 1933.

- Carta com que o professor Candido Motta se despede da Faculdade de Direito de São Paulo. Revista da Faculdade de Direito de Sáo Paulo, São Paulo, v. 33, n. 2, p. 357-365, 1937.

MOTTA FILHO, C. Relatório apresentado ao Dr. Secretário de Justiça pelo Dr. Candido Motta Filho, Director do serviço de Reeducação do Estado e Director do Reformatório Modelo 1935. Versão Facsimilar publicada em Boletim CCAPH (Centro de Documentaçáo e Apoio à Pesquisa em História da Educação da Universidade Sáo Francisco). Bragança Paulista, CDAPH-USF, v. 1, n. 2, 1998.

. Contagem Regressiva. Rio de Janeiro: José Olympio, 1972.

. Tratamento dos menores delinquentes e abandonados. São Paulo: Imprensa Oficial do Estado, 1935.

O COMBATE, de 25 de maio de 1920. Disponível em: <http://bndigital.bn.gov.br/ hemeroteca-digital/>. Acesso em: 6 set. 2018.

O COMBATE, de 24 de julho de 1917.

O COMBATE, de 18 de setembro de 1917.

O COMMERCIO DE SÃO PAULO, de 27 de outubro de 1895. Disponível em: <http:// bndigital.bn.gov.br/hemeroteca-digital/>. Acesso em: 6 set. 2018.

O COMMERCIO DE SÃO PAULO, de 27 de setembro de 1896.

O COMMERCIO DE SÃO PAULO, de 26 de novembro de 1902.

O COMMERCIO DE SÃO PAULO, de 22 de maio de 1908.

O COMMERCIO DE SÃO PAULO, de 02 de novembro de 1908.

O COMMERCIO DE SÃO PAULO, de 05 de novembro de 1908.

O COMMERCIO DE SÃO PAULO, de 14 de novembro de 1908.

O COMMERCIO DE SÃO PAULO, de 15 de novembro de 1908.

O COMMERCIO DE SÃO PAULO, de 24 de janeiro de 1909.

PERDOMO, R. P. Los juristas como intelectuales y el nacimiento de los estados naciones em América Latina. In: MYERS, J. Historia de los intelectuales em América Latina. I. 
La ciudad letrada, de la conquista al modernismo. Buenos Aires: Katz, p.168-183, 2008. REVISTA DA FACULDADE DE DIREITO (São Paulo). Apresentaçáo. vol. 38, 1942. p. 7-11.

REVISTA DA FACULDADE DE DIREITO DE SÃO PAULO. vol. 38, 1942.

SÁ, D. M. A ciência como profissão: médicos, bacharéis e cientistas no Brasil (18951935). Rio de Janeiro: Fiocruz, 2006.

SALLA, F. As prisóes em Sáo Paulo: 1822-1940. São Paulo: Annablume/Fapesp, 1999.

SALLA, F; ALVAREZ, M. C. Paulo Egídio e a Sociologia Criminal em São Paulo. Tempo Social - Revista de Sociologia da USP, São Paulo, v. 12, n. 1, p. 101-122, 2000.

SCHWARCZ, L. M. O espetáculo das raças: cientistas, instituições e questão racial no Brasil. São Paulo: Companhia das Letras, 1993.

SCHWARTZMAN, S. A força do novo: por uma sociologia dos conhecimentos modernos no Brasil. Revista Brasileira de Ciências Sociais, São Paulo, v. 2, n. 5, p. 48-66, outubro, 1987.

SIMÓES NETO, F. T. Os Bacharéis na Política e a Política dos Bacharéis. 2 v. São Paulo. Tese (Doutorado em Ciência Política) - Faculdade de Filosofia, Letras e Ciências Humanas. Universidade de São Paulo, 1983.

VENÂNCIO FILHO, A. Das Arcadas ao Bacharelismo. 2. ed. São Paulo: Perspectiva, 1982.

The new faces of liberal lawyers: an analysis of the trajectory of Candido Motta (1870-1942) 


\section{The new faces of liberal lawyers: an analysis of the trajectory of Candido Motta (1870-1942)}

\section{Abstract}

The purpose of this article is to analyze some aspects of the intellectual and political activity of members of Brazilian legal elites in the First Republic (1889-1930) in the frameworks of the socalled liberal bacharelism. In the same period, the Criminal Anthropology or "New Penal School" intended to innovate in the field of both Law and Medicine. Therefore, some physicians and jurists who defended this "school" had intellectual and political projection. We present here the trajectory of the jurist Candido Motta. He was a member of the elites, professor of the Law School in São Paulo and became a politician, by projecting himself as an intellectual who defended the New Penal School.

Keywords: Jurists. Criminal Law. Criminology. Legal Culture.

Recebido em: 26/03/2018

Aprovado em: 22/07/2018 